\title{
PEMETAAN PERSEPSI MAHASISWA JURUSAN TEKNIK MESIN FT UNP TERHADAP TEMPAT BEKERJA MENGGUNAKAN PENSKALAAN DIMENSI GANDA
}

\author{
Primawati $^{1 *}$, Yufrizal ${ }^{1}$, Abdul Marfuad ${ }^{1}$ dan Fazrol Rozi ${ }^{\mathbf{2}}$ \\ ${ }^{1}$ Jurusan Teknik Mesin, Fakultas Teknik, Universitas Negeri Padang \\ ${ }^{2}$ Jurusan Teknologi Informasi Politeknik Negeri Padang \\ *e-mail: primafazma@gmail.com
}

\begin{abstract}
Abstrak - Berbagai masalah dapat muncul dalam dunia profesi kerja, diantaranya disebabkan oleh kesalahan persepsi. Berdasarkan hasil observasi dan wawancara singkat dengan mahasiswa jurusan Teknik Mesin FT UNP didapat persepsi yang berbeda-beda dari setiap mahasiswa terhadap tempat bekerja/perusahaan yang sama. Penelitian ini bertujuan untuk memberikan gambaran visual mengenai persepsi mahasiswa Jurusan Teknik Mesin FT UNP terhadap tempat bekerja menggunakan Penskalaan Dimensi Ganda. Penelitian ini merupakan jenis penelitian deskriptif menggunakan Penskalaan Dimensi Ganda. Penskalaan Dimensi Ganda merupakan salah satu metode yang digunakan untuk memetakan persepsi mahasiswa terhadap 10 (sepuluh) tempat bekerja/perusahaan yang mendukung profesi engineering, yaitu PT. Chevron, PT. Pertamina, PT. PLN, PT. GMF AeroAsia, PT. Astra, PT. Krakatau Steel, PT. Bukit Asam, PT. RAPP, PT. Indah Kiat dan PT. Semen Padang yang diperoleh dengan menggunakan kuesioner. Hasil penelitian menunjukkan model yang terpilih adalah model tiga dimensi dengan nilai stress sebesar 0.05 dan kemampuan menjelaskan keragaman responden $\left(R^{2}\right)$ sebesar 98\%. PT. Chevron dan PT. Pertamina merupakan tempat bekerja/perusahaan yang dipersepsikan paling mirip oleh responden. PT. Semen Padang dan PT. Astra dipersepsikan paling tidak mirip oleh responden. Responden mempersepsikan kemiripan tempat bekerja/perusahaan berdasarkan atribut/kriteria gaji, tunjangan, visi dan misi tempat bekerja/perusahaan, supervisi tempat bekerja/perusahaan dan kondisi lingkungan tempat
\end{abstract} bekerja/perusahaan.

Kata kunci : Profesi, Engineering, Perusahaan, Dimensi Ganda, Stress

\begin{abstract}
Various problems may arise in workplace, which caused by misperceptions. Based on the results of the observation and short interview with mechanical engineering students of Padang State University obtained a different perceptions of each student to the workplace and the same company. This research aims of the studywere to provide an visual perception of mechanical engineering students of Padang State University to workplace by using a Multidimension Scalling. This study is a descriptive research using a Multidimensional Scaling. The Multidimensional Scalling is one of method that use to map the perceptions of 10 places of work or the company which supports the engineering profession, that are PT. Chevron, PT. Pertamina, PT. PLN, PT. GMF AeroAsia, PT. Astra, PT. Krakatau Steel, PT. Bukit Asam, PT. RAPP, PT. Indah Kiat dan PT. Semen Padang which is obtained by direct survey questionnaire. The study showed that the selected model is three-dimensional model with a stress value of 0,05 and the ability to explain the diversity of respondents $\left(R^{2}\right)$ of $98 \%$. PT. Chevron and PT. Pertamina are a place of work or most similar companies perceived by respondent. The workplace or company that is considered the most no resemblance by the respondent are PT. Semen Padang and PT. Astra International.
\end{abstract}

Keyword : Professions, Engineering, Company, Multidimensional, Stress.

Copyright () 2017 INVOTEK. All rights reserved

\section{Pendahuluan}

Engineer merupakan salah satu muara profesi bagi alumni mahasiswa Fakultas Teknik, salah satunya adalah Jurusan Teknik Mesin. Profesi engineer kian hari semakin menghadapi tantangan yang semakin berat. Kesiapan yang menyangkut profesionalisme profesi seperti keahlian (Skill), karakter (Character), dan pengetahuan (Knowledge) mutlak diperlukan. Pendidikan tinggi untuk 
jurusan Teknik Mesin seharusnya tidak hanya menekankan pada kebutuhan keterampilan (Skill) dan pengetahuan (Knowledge) yang bersifat teoritis, tetapi juga harus mampu mensosialisasikan kepada mahasiswanya dengan hal-hal yang berhubungan dengan dunia praktik dan lingkungan kerja profesi engineer, sehingga lulusan jurusan Teknik Mesin lebih bisa berfikir real terhadap dunia kerja yang nanti akan dihadapi. Namun dalam kenyataannya hal tersebut sangat jarang didapat oleh mahasiswa dari pihak kampus, sehingga membuat mahasiswa harus mempersepsikan sendiri tempat bekerja sebatas dari informasi yang mereka miliki. Hal tersebut tentunya akan dapat menimbulkan berbagai macam masalah yang dikarenakan kesalahan persepsi terhadap tempat bekerja ataupun pekerjaan tersebut.

Persepsi adalah proses yang menyangkut masuknya pesan dan informasi ke dalam otak manusia. Informasi dan pesan yang diterima tersebut muncul dalam bentuk stimulus yang merangsang otak untuk mengolah lebih lanjut yang kemudian mempengaruhi seseorang dalam berperilaku [4]. Berdasarkan hal itu tentunya persepsi mahasiswa jurusan Teknik Mesin mengenai tempat bekerja dan pekerjaan nantinya akan menjadi sumbangan bahan acuan untuk memilih tempat bekerja dan jenis pekerjaan setelah lulus dari jenjang pendidikan tinggi. Berdasarkan hasil wawancara pendahuluan yang penulis lakukan kepada beberapa orang mahasiwa jurusan Teknik Mesin FT UNP, khusunya mahasiswa Program Studi Pendidikan Teknik Mesin (S-1), menunjukkan bahwa mahasiswa jurusan Teknik Mesin lebih cenderung menginginkan untuk dapat menekuni profesi sebagai engineer dibandingkan memilih untuk menjalankan profesi sebagai guru.

Disisi lain mahasiswa jurusan Teknik Mesin Program Studi Teknik Mesin (D-3) memang diprogram untuk memiliki kemampuan dan keterampilan sebagai Ahli Madya dibidang mesin untuk menekuni dunia engineer. Berdasarkan hal itu, penulis melakukan observasi melalui kuesioner pendahuluan untuk melihat persepsi awal mahasiswa jurusan Teknik Mesin FT UNP mengenai tempat bekerja/perusahaan yang mendukung profesi engineering. Hasil observasi mengindikasikan mahasiswa jurusan Teknik Mesin FT UNP memiliki persepsi yang berbeda -beda terhadap tempat bekerja/perusahaan tergantung pada bagaimana dan seberapa banyak informasi yang diperoleh terhadap tempat bekerja dan pekerjaan tersebut. Mahasiswa jurusan Teknik Mesin FT UNP mempersepsikan tempat bekerja yang baik berdasarkan patokan yang berbeda-beda, seperti: tinggi rendahnya gaji, minat terhadap pekerjaan, lokasi tempat bekerja, stabilitas, tunjangan, dan lain-lain [3].

Meskipun objek yang dipersepsikan sama, dalam hal ini tempat bekerja, namun antara mahasiswa satu dengan mahasiswa lainnya memiliki persepsi yang berbeda terhadap tempat bekerja yang sama. Perbedaan persepsi mahasiswa jurusan Teknik Mesin FT UNP tentang kemiripan tempat bekerja bagi profesi engineering seperti yang dijelaskan di atas lebih jauh dapat dijelaskan jika dipetakan dalam sebuat peta persepsi.

Salah satu analisis statistika yang dapat menganalisis data kemiripan /ketakmiripan antar objek adalah Penskalaan Dimensi Ganda (Multidimensional Scaling). Persepsi mahasiswa jurusan Teknik Mesin FT UNP terhadap tempat bekerja/perusahaan di atas merupakan contoh nyata yang dapat penulis lihat berdasarkan hasil observasi yang penulis lakukan kepada beberapa orang mahasiswa di lingkungan jurusan Teknik Mesin FT UNP. Berdasarkan hal tersebut perlu rasanya dilakukan penelitian mengenai persepsi mahasiswa Jurusan Teknik Mesin FT UNP terhadap tempat bekerja dengan menggunakan penskalaan dimensi ganda.

\section{Metode}

Penelitian ini merupakan jenis penelitian deskriptif. Penggambaran variabel pada penelitian ini, dalam hal ini adalah persepsi digambarkan/dipetakan menggunakan teknik Penskalaan Dimensi Ganda (Multidimensional Scaling). Penelitian tersebut dapat diharapkan memberikan gambaran visual mengenai:

1. Derajat kemiripan persepsi mahasiswa jurusan Teknik Mesin FT UNP terhadap tempat bekerja/perusahaan.

2. Data peringkat untuk masing-masing tempat bekerja/perusahaan berdasarkan kriteria yang ditetapkan.

3. Atribut/kriteria yang digunakan oleh mahasiswa jurusan Teknik Mesin FT UNP dalam mempersepsikan tempat bekerja/perusahaan. 
Penelitian ini mengasumsikan bahwa responden memberikan penilaian berdasarkan kemiripan yang menggunakan konsep data ordinal. Responden diminta memberikan nilai peringkat pada pasangan tempat bekerja/perusahaan, angka 1 untuk pasangan tempat bekerja/perusahaan yang dianggap paling tidak mirip/berbeda dan angka 5 untuk pasangan tempat bekerja/perusahaan yang sangat mirip/tepat sama. Adapun tempat bekerja/perusahaan yang telah ditetapkan berdasarkan data hasil observasi yang telah peneliti lakukan di lingkungan jurusan Teknik Mesin FT UNP adalah: PT. Chevron, PT. Pertamina, PT. PLN, PT. GMF AeroAsia, PT. Astra International, PT. Krakatau Steel, PT. Bukit Asam, PT. RAPP, PT. Indah Kiat dan PT. Semen Padang.

Selain memberikan nilai peringkat pasangan tempat bekerja/perusahaan, responden juga memberikan penilaian terhadap atribut/kriteria tempat bekerja. Adapun pengidentifikasian atribut yang didapat dari data hasil observasi yang telah dilakukan adalah: Gaji, tunjangan, minat, visi dan misi tempat bekerja, supervisi tempat bekerja, stabilitas tempat bekerja, pengembangan kompetensi, lokasi tempat bekerja, kondisi lingkungan tempat bekerja, dan relasi. Penelitian tentang persepsi mahasiswa jurusan Teknik Mesin FT UNP terhadap tempat bekerja yang dilakukan menggunakan beberapa teknik dalam menganalisis data yang diperoleh. Teknik analisis data yang digunakan adalah

\section{Analisis Penskalaan Dimensi Ganda}

Teknik analasis Penskalaan Dimensi Ganda (Multidimensional Scaling) dalam penelitian ini digunakan untuk menghasilkan peta persepsi (Perceptual map) mahasiswa jurusan Teknik Mesin FT UNP terhadap kemiripan beberapa tempat bekerja/perusahaan yang dipersepsikan. Tingkat keandalan (Reliability) instrumen penelitian dalam penskalaan dimensi ganda dilihat dari nilai $R$-Squere $\left(R^{2}\right) . \quad R^{2}$ mengindikasikan proporsi varian data yang dapat dijelaskan oleh Penskalaan Dimensi Ganda, semakin besar $R^{2}\left(R^{2}\right.$ mendekati 1) maka semakin baik pula model yang diperoleh.

Penilaian kesahihan (Validity) pada penskalaan dimensi ganda dilihat dari ukuran nilai stress. Nilai stress dipergunakan sebagai ukuran ketidakcocokan/ketidaktepatan suatu model pemecahan Penskalaan Dimensi Ganda [2]. Untuk interpretasi berlaku prinsip semakin rendah stress, semakin baik model penskalaan dimensi ganda yang dihasilkan.

Tabel 1. Standar Nilai Stress Kruskal

\begin{tabular}{|c|c|}
\hline Stress (Percent) & Goodness of fit \\
\hline 20 & Poor \\
\hline 10 & Fair \\
\hline 5 & Good \\
\hline 2,5 & Excellent \\
\hline 0 & Perfect \\
\hline
\end{tabular}

Sumber : Bilson (2005:269)

\section{Analisis Regresi}

Analisis regresi pada penelitian digunakan untuk menentukan atribut/kriteria yang digunakan oleh mahasiswa jurusan Teknik Mesin FT UNP dalam mempersepsikan kemiripan tempat bekerja/perusahaan yang dipersepsikan. Nilai koefisien determinasi $\left(R^{2}\right)$ masing-masing atribut/kriteria tempat bekerja/perusahaan yang didapat dari analisis ini akan dijadikan sebagai acuan untuk pelabelan dimensi pada peta persepsi yang didapat dari hasil analisis penskalaan dimensi ganda yang dilakukan sebelumnya. Koefisien korelasi ganda menunjukkan korelasi antara proyeksi objek dengan nilai atribut/kriteria. Jika nilai koefisien rendah, maka dengan aman dapat disimpulkan bahwa subjek tidak menggunakan atribut dalam mengadakan penilaian kemiripan [5].

\section{HASIL DAN PEMBAHASAN}

Aplikasi penskalaan dimensi ganda dalam penelitian ini digunakan untuk meneliti tentang persepsi responden terhadap 10 tempat bekerja/perusahaan yang mendukung profesi engineering. Diasumsikan bahwa responden memberikan penilaian berdasarkan kemiripan yang menggunakan konsep jarak berskala ordinal. Berdasarkan data mentah yang diperoleh dari intrumen penelitian, didapat data rata-rata kemiripan tempat bekerja/perusahaan yang dipersepsikan oleh responden seperti pada Tabel 2 berikut:

Tabel 2. Rata -rata penilaian responden terhadap derajat kemiripan masing -masing pasangan tempat bekerja 


\begin{tabular}{|c|c|c|c|c|c|c|c|c|c|c|}
\hline & Chesturn & Potlamina: & PIN & GMF & Afras & $\begin{array}{c}\text { Krakaluu } \\
\text { Stoci }\end{array}$ & $\begin{array}{l}\text { Bukit } \\
\text { Asamm }\end{array}$ & RAPP & $\begin{array}{c}\text { Irralah } \\
\text { Kist }\end{array}$ & $\begin{array}{l}\text { Saman } \\
\text { Padang }\end{array}$ \\
\hline Shevrna & . & . & . & . & . & . & - & - & - & - \\
\hline Partanina & 3.97 & & & . & . & & - & . & . & . \\
\hline I'LN & 2.40 & 272 & . & . & . & . & - & - & - & . \\
\hline GMT: & 2.43 & 267 & $23 !$ & & & & & & & \\
\hline Astra & 2.19 & 244 & 2.27 & 2.74 & - & . & - & . & - & . \\
\hline $\begin{array}{r}\text { Kraksales } \\
\text { Steed }\end{array}$ & 2.09 & 2.11 & 2.02 & 2.14 & 230 & & . & - & . & . \\
\hline $\begin{array}{l}\text { Butkit } \\
\text { Asam }\end{array}$ & 2.00 & 216 & 2.05 & 1.79 & 183 & 24! & - & - & - & - \\
\hline RAPP & 1.75 & 203 & 1.83 & 1.87 & 192 & 2.50 & 2.37 & . & . & . \\
\hline $\begin{array}{c}\text { Indain } \\
\text { Kial }\end{array}$ & 1.90 & 195 & 196 & 19 ! & 185 & 249 & 2.51 & 3.6 & . & . \\
\hline $\begin{array}{l}\text { Semea } \\
\text { Padurg }\end{array}$ & 1.93 & $1 \times 2$ & 1.77 & 1.89 & 176 & 236 & 2.53 & 2.47 & 2.39 & . \\
\hline
\end{tabular}

Data rata-rata kemiripan pasangan tempat bekerja pada Tabel 2 dikonfersikan ke dalam bentuk peringkat maka akan menghasilkan Tabel 3 sebagai berikut:

Tabel 3. Peringkat pasangan tempat bekerja berdasarkan kemiripan

\begin{tabular}{|c|c|c|c|c|c|c|c|c|c|c|}
\hline & (hevrom & Pertamina & PIN & కiMF & AEr & $\begin{array}{c}\text { Srakatau } \\
\text { Stezi }\end{array}$ & $\begin{array}{l}\text { Bukit } \\
\text { A.am }\end{array}$ & RAI'P & $\begin{array}{l}\text { Gdah } \\
\text { Kiall }\end{array}$ & $\begin{array}{l}\text { Semen } \\
\text { Paxkang }\end{array}$ \\
\hline Cacreon & - & - & . & . & . & - & - & - & - & . \\
\hline Pirtarning & 1 & . & . & . & - & . & - & - & - & . \\
\hline PIN & 14 & 4 & & & & & . & & - & \\
\hline (iM) & 12 & 5 & 18 & & & & . & & - & \\
\hline Aista & 21 & 11 & 20 & 3 & . & . & - & - & - & . \\
\hline $\begin{array}{r}\text { Krakatu } \\
\text { Sted }\end{array}$ & 25 & 24 & 28 & 23 & 19 & & - & . & - & . \\
\hline $\begin{array}{l}\text { Bukit } \\
\text { Asant }\end{array}$ & 29 & 22 & 26 & 42 & 40 & 13 & - & . & - & . \\
\hline RAPP & 45 & 27 & 39 & 37 & 33 & $B$ & 16 & . & - & . \\
\hline $\begin{array}{l}\text { Ind:ht } \\
\mathrm{K}: \mathrm{at}\end{array}$ & 35 & 3) & 30 & 34 & 38 & 9 & 7 & 2 & - & - \\
\hline $\begin{array}{l}\text { Sernert } \\
\text { Padang }\end{array}$ & 32 & $4]$ & $4 ?$ & 36 & 44 & 17 & 5 & 10 & 15 & . \\
\hline
\end{tabular}

Berdasarkan Tabel 3 dapat dilihat bahwa tempat bekerja yang memiliki peringkat tertinggi adalah PT. Chevron dan PT. Pertamina, pasangan tempat bekerja tersebut dipersepsikan oleh responden sebagai pasangan tempat bekerja yang memiliki kemiripan paling besar dibandingkan dengan pasangan tempat bekerja lainnya. Pasangan tempat bekerja lainnya yang juga dipersepsikan memiliki kemiripan oleh responden adalah pasangan tempat bekerja PT. RAPP dan PT. Indah Kiat. Pasangan tempat bekerjaPT. Chevron dan PT. RAPP adalah pasangan tempat bekerja yang dianggap paling tidak banyak memiliki kemiripan oleh responden.

Tabel 4. Nilai Stress

\begin{tabular}{|c|c|c|}
\hline \multicolumn{3}{|c|}{ Stress } \\
\hline Dimensi 1 & Dimensi 2 & Dimensi 3 \\
\hline 0.11978 & 0.08816 & 0.05127 \\
\hline
\end{tabular}

Penentuan dimensi yang digunakan untuk pemetaan objek dalam penskalaan dimensi ganda ditentukan berdasarkan nilai stress dari masingmasing dimensi. Nilai stress yang kecil pada suatu dimensi merupakan indikasi terbaik dalam penyelesaian penskalaan dimensi ganda. Pada Tabel 4 di atas dapat diketahui pemetaan objek pada ruang dimensi tiga menghasilkan nilai stress sebesar 0.05127. Berdasarkan standar nilai stress yang ditetapkan oleh Kruskal, maka dapat dilihat bahwa pemetaan objek pada ruang dimensi tiga berada pada kategori good. Artinya penyelesaian pada ruang dimensi tiga mampu dengan baik merefleksikan kemiripan antar masing-masing objek. Setelah melakukan beberapa kali iterasi dengan menggunakan software SPSS v.16, maka didapat perceptual map sebagai berikut:

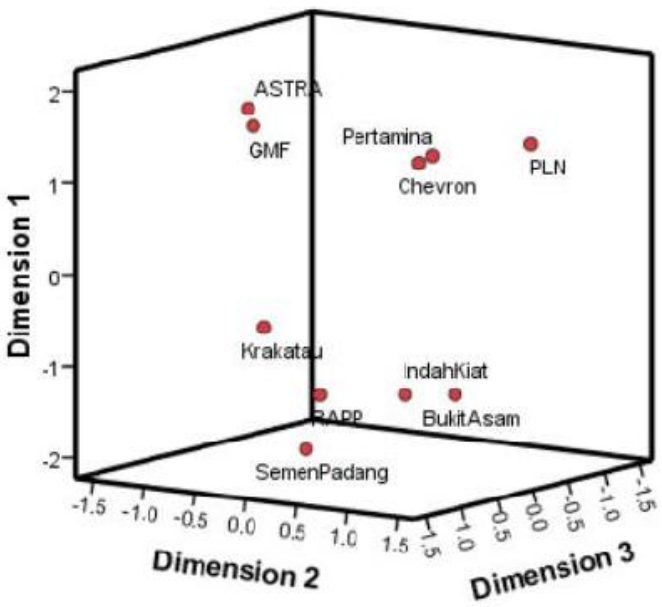

Gambar 1. Pemetaan objek pada ruang dimensi tiga

Penentuan atribut yang digunakan oleh responden dalam menentukan kemiripan pasangan tempat bekerja/perusahaan digunakan nilai dari koefisien determinasi $\left(R^{2}\right)$ yang diperoleh pada analisis regresi. Koefisien determinasi $\left(R^{2}\right)$ digunakan untuk menjelaskan bagaimana kuatnya hubungan antar kriteria dengan tempat bekerja. Jika suatu kriteria memiliki koefisien determinasi yang tinggi maka kriteria tersebut digunakan oleh responden dalam menentukan kemiripan antar pasangan tempat bekerja. Berdasarkan pengolahan data maka didapat koefisien determinasi masingmasing atribut pada tabel 5 di bawah ini: 
Tabel 5. Koefisien Determinasi $\left(R^{2}\right)$ Masing- Masing Atribut/Kriteria

\begin{tabular}{|c|c|c|}
\hline & Atribut/Kriteria & $\begin{array}{l}\text { Koefisiens } \\
\text { Determinasi } \\
\left(R^{2}\right)\end{array}$ \\
\hline 1 & Gaji & 0.838 \\
\hline 2 & Tunjangan & 0.832 \\
\hline 3 & Minat & 0.784 \\
\hline 4 & $\begin{array}{l}\text { Visi dan Misi Tempat } \\
\text { Bekerja/Perusahaan }\end{array}$ & 0.879 \\
\hline 5 & $\begin{array}{l}\text { Supervisi Tempat } \\
\text { Bekerja/Perusahaan }\end{array}$ & 0.863 \\
\hline 6 & $\begin{array}{l}\text { Stabilitas Tempat } \\
\text { Bekerja/Perusahaan }\end{array}$ & 0.776 \\
\hline 7 & Pengembangan Karir & 0.726 \\
\hline 8 & $\begin{array}{l}\text { Lokasi Tempat } \\
\text { Bekerja/Perusahaan }\end{array}$ & 0.673 \\
\hline 9 & $\begin{array}{l}\text { Kondisi Lingkungan } \\
\text { Tempat } \\
\text { Bekerja/Perusahaan }\end{array}$ & 0.840 \\
\hline 10 & Relasi & 0.551 \\
\hline
\end{tabular}

Berdasarkan koefisien determinasi $\left(R^{2}\right)$ masing-masing atribut pada Tabel 5, maka diketahui atribut yang memiliki nilai koefisien determinasi $\left(R^{2}\right)$ yang mendekati nilai 1 adalah: atribut gaji, tunjangan, visi dan misi tempat bekerja, supervisi tempat bekerja, dan kondisi lingkungan tempat bekerja. Berdasarkan hal itu dapat diketahui atribut yang digunakan responden dalam menentukan kemiripan tempat bekerja dari setiap dimensi menggunakan metode pendekatan subyektif. Untuk penamaan dimensi satu dapat kita gunakan atribut gaji dan tunjangan. Dimensi dua menggunakan atribut. Visi dan misi tempat bekerja dan supervisi tempat bekerja. Sedangkan untuk penamaan dimensi tiga dapat digunakan atribut kondisi lingkungan tempat bekerja. Setelah nama dimensi diidentifikasi, maka akan dihasilkan perceptual map yang baru

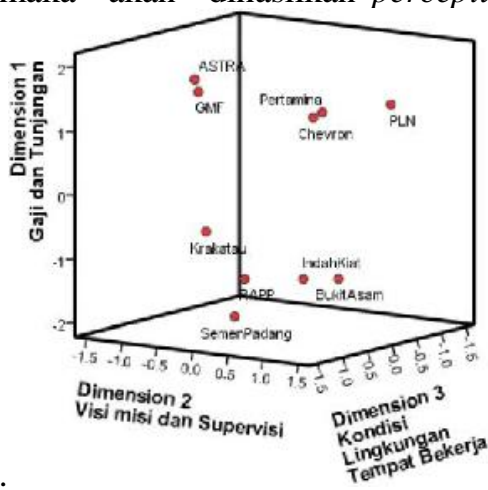

Gambar 2. Pemetaan Objek pada Ruang Dimensi Tiga

Gambar di atas dapat diinterpretasikan bahwa

Pemetaan Persepsi Mahasiswa .....(Primawati et al.)
PT. Astra International dan PT. GMF AeroAsia adalah tempat bekerja yang memiliki kemiripan dari atribut pada dimensi satu dan dimensi tiga, yaitu atribut gaji dan tunjangan serta kondisi lingkungan tempat bekerja yang baik. PT. Chevron, PT. Pertamina dan PT. PLN Persero adalah tempat bekerja yang dianggap mirip dari segi atribut gaji dan tunjangan yang baik, serta visi misi tempat bekerja dan supervisi tempat berkerja yang jelas dan baik. PT. Indah Kiat Pulp and Paper dan PT. Bukit Asam adalah tempat bekerja yang dipersepsikan sebagai tempat bekerja yang memiliki kemiripan dari atribut gaji dan tunjangan yang buruk namun dengan kondisi lingkungan tempat bekerja yang dapat dikatakan baik. PT. Krakatau Steel dan PT. RAPP merupakan tempat bekerja yang memiliki kemiripan dari atribut gaji dan tunjangan yang buruk, namun dengan atribut kondisi lingkungan tempat bekerja yang baik. Kemudian PT Semen Padang dipersepsikan sebagai temapat bekerja dengan visi misi tempat dan supervisi tempat yang jelas dan baik, serta kondisi lingkungan tempat bekerja.

\section{KESIMPULAN}

Berdasarkan hasil analisis data yang diperoleh dalam penelitian ini dapat ditarik kesimpulan sebagai berikut:

1. PT. Chevron dan PT Pertamina merupakan tempat bekerja yang dianggap paling mirip oleh mahasiswa jurusan Teknik Mesin FT UNP.

2. PT Semen Padang dan PT PLN merupakan tempat bekerja yang paling tidak mirip dipersepsikan oleh mahasiswa jurusan Teknik Mesin FT UNP.

3. Mahasiswa jurusan Teknik Mesin FT UNP mempersepsikan kemiripan tempat bekerja berdasarkan atribut gaji, tunjangan, visi dan misi tempat bekerja, supervisi tempat bekerja, dan kondisi lingkungan tempat bekerja/perusahaan

\section{DAFTAR PUSTAKA}

[1] Bilson, Simamora. Analisis Multivariat Pemasaran. Jakarta: Gramedia Pustaka Utama. (2005) 
[2] J. Supranto. Analisis Mutivariat Arti dan Intepretasi. Jakarta: Rineka Cipta. (2004)

[3] Dwiprima Elvanny $M$ dan Mhd Irsan. Korelasi Minat Berwirausaha dengan Kinerja Praktek Kerja Industri Siswa SMK. Padang. Jurnal Invotek Vol 17 No 1 April 2017

[4] Slameto. Belajar dan Faktor yang mempengaruhinya. Jakarta: Rineka Cipta. (2003)

[5] Yuda Esdin Sutanto. Skalar Multidimensi. (Skripsi). Fakultas SAIN dan Teknologi Universitas Sanata Dharma. (2007).

\section{Biodata Penulis}

Primawati, lahir di Padang, 6 Maret 1986. Sarjana Sains di Jurusan Matematika UNAND 2008. Tahun 2011 memperoleh gelar Magister Sains di jurusan Matematika pasca sarjana UNAND. Staf pengajar di jurusan Teknik Mesin FT UNP sejak tahun 2012- sekarang.

Yufrizal, dilahirkan di Padang, 21 April 1961. Menyelesaikan S1 pada jurusan Pendidikan Teknik Mesin IKIP Padang dan pendidikan Pascasarjana (S2) Magister Pendidikan di jurusan Teknologi Pendidikan Program Pascasarjana UNP. Sejak tahun 1986 menjadi staf pengajar tetap di jurusan Teknik Mesin Fakultas Teknik Universitas Negeri Padang.

Abdul Marfuad, lahir di Lintau, 13 Maret 1994. Sarjana Pendidikan di Jurusan Teknik Mesin FT UNP 2016.

Fazrol Rozi, dilahirkan di Tembilahan, 21 Juli 1986. Menyelesaikan S1 pada jurusan Matematika UKM (University Kebangsaan Malaysia) 2007. Tahun 2010 memperoleh gelar Magister Sains di jurusan Matematika UKM (University Kebangsaan Malaysia). Staf pengajar di jurusan Teknologi Informasi Politeknik Negeri Padang sejak tahun 2010- sekarang. 